\title{
MAPEAMENTO DAS PROMOTORIAS DE JUSTIÇA DA MESORREGIÃO DO SUL ESPÍRITO-SANTENSE
}

\author{
Stéphanie Lã Ferrari ${ }^{1}$ \\ Jéferson Luiz Ferrari ${ }^{2}$
}

Resumo: As Promotorias de Justiça são o contato direto do Ministério Público com o cidadão. Este trabalho teve como objetivo mapear as Promotorias de Justiça da Mesorregião do Sul Espírito-Santense visando melhor compreender e popularizar as funções dessas Instituições. Foi construída uma base de dados geográficos com informações referentes à localização geográfica das promotorias de Justiça que integram a referida região, bem como a microrregião, área e população dos municípios nos quais elas se localizam. Foram identificadas 22 Promotorias de Justiça e gerado um mapa de localização das promotorias. A microrregião que apresenta o maior número de Promotorias de Justiça é a microrregião de Cachoeiro de Itapemirim com o total de 10 promotorias, seguida pela microrregião de Alegre, que possui 9 promotorias, e de Itapemirim, com 3 promotorias.

Palavras-chave: Cidadania; Direito; Geoprocessamento.

\footnotetext{
${ }^{1}$ Graduanda em Direito/Faculdade de Direito de Cachoeiro de Itapemirim, Cachoeiro de Itapemirim/ES, Brasil. Email: laferrari.stephanie@gmail.com.

2 Professor de ensino básico, técnico e tecnológico/Instituto Federal do Espírito Santo-Campus de Alegre, Alegre/ES, Brasil. E-mail: ferrarijluiz@gmail.com.
} 